\title{
In Vitro Characterization and Evaluation of Silver Nanoparticles Cytotoxicity on Human "Liver and Breast" Cancer Cells Versus Normal Melanocytes
}

\author{
Rania Sayed ${ }^{1}$, Dina Sabry², Gomaa Mostafa-Hedeab ${ }^{3,4}$ and Hanan HM Ali ${ }^{5}$ \\ Original \\ Article

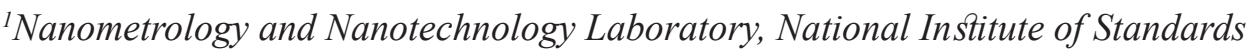 \\ ${ }^{2}$ Medical Biochemistry and Molecular Biology, Faculty of Medicine, Cairo University \\ ${ }^{3}$ Pharmacology Department, Faculty of Medicine, Beni-Suef University, Beni-Suef, Egypt \\ ${ }^{4}$ Pharmacology Department, Faculty of Medicine, Jouf University, Saudi Arabia \\ ${ }^{5}$ Department of Pathology, Faculty of Medicine, Cairo University
}

\begin{abstract}
Introduction: In the field of medicine, silver nanoparticles (Ag NPs) with their distinctive characteristics represent an interesting new cancer therapy. Cancer is a serious disease, despite the recent advances in its treatment; there are still some cases that are resistant to the current therapy.

Aim of the work: This study aimed at examining the characteristics of 2 forms of silver nanomaterial (Ag NPs 1 and Ag NPs 2) and investigating their effect on breast cancer (MCF7) and liver cancer (HEP-G2) as well as on human normal melanocytes cell lines (HBF4).

Materials and methods: It was found that both samples of nanoparticles have negative surface charge and their mean sizes were $9.02 \mathrm{~nm}$ and $24.6 \mathrm{~nm}$ respectively. Both Ag NPs 1 and Ag NPs 2 had a dose- dependent cytotoxicity on MCF7 and HEP-G2 with negligible effect on normal cell line (HBF4) measured by MTT assay.

Results: Inhibitory Concentration 50 of Ag NPs1 and Ag NPs2 were 20.06 and $16.03 \mathrm{nmol} / \mathrm{ml}$ respectively. The resultant cell death was via apoptosis as illustrated by the inverted light microscopy. RT-PCR assessment revealed significant upregulation in Caspase 3 gene expression in the malignant cell lines exposed to each silver nanomaterials and remarkable downregulation VEGF and upregulation in TNF- $\alpha$ in either cancer cell line exposed to Ag NPs2 only. Meanwhile, the change in these cellular markers was minimal in normal human melanocyte cell line.

Conclusion: This study indicates that silver nanoparticles can be used as anticancer agent with minimal effect on normal tissues. The cell viability depends not only on the size of Ag NPs but also their shape, surface charge and degree of repulsion between particles and aggregation.
\end{abstract}

Received: 01 January 2019, Accepted: 10 April 2019

Key Words: Breast cancer cells; characterization; cytotoxicity, liver cancer cell lines; silver nanoparticles.

Corresponding Author: Rania Sayed, PhD, Nanometrology and Nanotechnology Laboratory, National Institute of Standards, P. O. Box 136, Giza 12211, Egypt, Tel.: +20 1005567106, E-mail: rsayed.nis@gmail.com

ISSN: $1110-0559$, Vol. 42, No. 3

\section{INTRODUCTION}

Nanomedicine is an upcoming field that could potentially make a major impact on human health ${ }^{[1]}$. Engineered nanoparticles (NPs) are commercially produced materials having at least one dimension less than $100 \mathrm{~nm}^{[2]}$. Nanotechnology has brought a great revolution in industry. Due to their excellent physicochemical and electrical properties, nanomaterials have gained considerable attraction in the field of biotechnology and electronics ${ }^{[3]}$. In the field of medicine, NPs are being employed as a novel delivery system for drugs, proteins, DNA, and monoclonal antibodies $^{[4]}$.

Among all the metallic nanomaterials, silver nanoparticles (Ag NPs) hold a special attention for their use in different research areas due to their unique physical properties $^{[5]}$. They are commonly used for antimicrobial coatings and biomedical devices, as they constantly release a low dose of silver ions to prevent bacterial infection ${ }^{[6]}$. Consequently, scientists are interested in using nanomaterials as a novel tool that can specifically target tumor cells ${ }^{[7]}$.

Cancer is a complex disease characterized by uncontrolled proliferation and dissemination of abnormal cells caused by a combination of genetic and environmental factors ${ }^{[8]}$. The fundamental causes for development of cancer are abnormalities in the growth factors or dysregulation of apoptosis, which is a programmed cell death that involves the controlled dissociation of intracellular components 
without triggering inflammation or damage to surrounding cells $^{[9]}$. There are numerous genes controlling cell growth and the process of apoptosis, among them VEGF is the key mediator of angiogenesis in cancer, and the growth of tumor cells ${ }^{[10]}$. Additionally, Caspase 3 is among executive caspases that induces cell death via apoptosis and its over expression or loss were reported in malignant tumors ${ }^{[11-13]}$. Likewise, TNF- alpha plays a role in controlling apoptotic cell death, as well as cell growth ${ }^{[14]}$.

Despite of the recent advances in treatment of malignant tumors with availability of target therapy, there are still challenging cases that are resistant to the available systemic therapies ${ }^{[15,16]}$. Moreover, these traditional chemotherapeutic agents have numerous side effects ${ }^{[17]}$. Therefore, the challenge is to identify effective molecules that have high specificity and sensitivity targeting malignant cells with less impact on normal tissues. This study was designed to examine the physical characteristics of 2 different samples of sliver nanoparticles and investigate their potential cytotoxicity on normal human melanocytes, liver cancer (HEP-G2) and breast cancer cell lines (MCF7). The second objective was to evaluate their effects on Caspase 3, TNF- $\alpha$ and VEGFgenes' expressions.

\section{MATERIAL AND METHODS}

\section{Characterization of silver nanoparticles}

Two samples of silver nanoparticles were purchased from Sigma-Aldrich. Fresh Ag NPs stock solutions were prepared immediately before testing using deionized (DI) water.

\section{- Zeta potential measurements}

The samples obtained were designated as AgNPs1 and AgNPs2. Their surface charge and average size distribution were determined by Zeta potential and dynamic light scattering (DLS) using a Zetasizer (Nano ZS, Malvern, UK) with a He-Ne laser (633 nm) using a non-invasive backscatter method (detection at 173 o scattering angle) at $25 \mathrm{oC}$. The stability of Ag NPs was quantified by measuring the value of Zeta potential, which indicates the degree of repulsion between charged particles in Ag nanosuspensions.

- High Resolution Transmission Electron Microscope (HR-TEM)

Shapes and sizes of both specimens were investigated by high resolution transmission electron microscope (HRTEM, Jeol-Jem2100, Japan) operated at $200 \mathrm{KV}$. A drop of Ag NPs suspension was placed on a carbon coated copper grid and dried under infrared lamp for characterization.

\section{Cell culture}

American Type Culture Collection (ATCC) cell lines of HEP-G2 (liver carcinoma cell line), MCF7 (breast adenocarcinoma) and melanocyte normal cell line (HBF4) were supplied from Tissue Culture DepartmentVACSERA- EGYPT. Sigma-Aldrich Chemical Co., St. Louis, Mo, U.S.A., was the source of the following chemicals: tris EDTA buffer and sulfo-rhodamine-B stain.
All cell lines used were of Homo sapiens origin. They were grown in a sterile tissue $75 \mathrm{~cm} 3$ flask in complete medium containing Dulbecco's modified Eagle's medium (DMEM) supplemented with 10\% fetal bovine serum (FBS) and antibiotics $(100 \mathrm{U} / \mathrm{ml}$ penicillin and $100 \mathrm{mg} / \mathrm{ml}$ streptomycin) in $5 \% \mathrm{CO} 2$ incubator at $37^{\circ} \mathrm{C}$.

\section{Calculation of Inhibitory Concentration 50 (IC50) of Ag NPs1 and Ag NPs2}

The potential cytotoxicity of Ag NPs1 and Ag NPs2 was tested using the method of Skehan et al. ${ }^{[18]}$. To calculate IC50, HEP-G2 cells were plated in 96-multiwell plate (104cells/well) for $24 \mathrm{hrs}$ before treatment with the either Ag NPs to allow attachment of cell to the wall of the plate. Different concentration of each material $(5,12.5,25,50 \mathrm{nmole} / \mathrm{ml})$ were added to the cell monolayer. The relation between surviving fraction and silver nano concentrations was plotted to get the survival curve of HEP-G2 cells after treatment with either material. The IC50 of Ag NPs1 was20.6 nmole/ml and of Ag NPs2 was $16.3 \mathrm{nmole} / \mathrm{ml}$. Then, according to IC50 concentration, Ag NPs1 and Ag NPs2 preparations were applied to the three types of studied cell lines for 24 hours. For further PCR work the cells were propagated in 24 well tissue culture plates containing 105 cells $/ 500 \mu \mathrm{l}$ per well.

\section{Cytotoxic MTT assay}

The MTT Reagent and detergent solution were obtained from TACS TM TREVIGEN ®8404Hegerman Ct. Gaithersburg, supplied ready to use. The optical Density (O.D) values were measured at $450 \mathrm{~nm}$ using an ELISA reader (Dynatech MRX 5000; Dynex, Chantilly, VA). The experiment was carried out in triplicates and the average of the viable cells was calculated. A graph was plotted between the percentage of cell viability and concentration.

\section{Quantitative RT-PCR}

Real time PCR was performed for quantitative genes expression level of Caspase 3, TNF- $\alpha$ and VEGF. Different cell lines of all studied groups were trypsinized and centrifuged to form cell pellet. Cell lysis buffer was added to cell pellet. RNA was extracted from cell lysate using Thermo Fisher Scientific Inc. Germany kit (GeneJET, Kit, \#K0732) according to manual instructions. Ten ng of total RNA from each sample were used for reverse transcription with subsequent amplification with Bioline a median life science company, UK (SensiFASTTMSYBR $® H i-R O X)$ one-step Kit (catalog no. PI-50217 V) in a 48-well plate using the Step One instrument (Applied Biosystem, USA). Thermal profile was as follows: $45^{\circ} \mathrm{C}$ for 15 minutes one cycle (for c DNA synthesis), 10 minutes at $95^{\circ} \mathrm{C}$ for reverse transcription enzyme inactivation followed by 40 cycles PCR amplification. Each cycle was 10 seconds at $95^{\circ} \mathrm{C}, 30$ seconds at $60^{\circ} \mathrm{C}$ and 30 seconds at $72^{\circ} \mathrm{C}$. Changes in the expression level of each target gene were normalized relative to the mean critical threshold (CT) values of 18 sRNA as housekeeping gene by $\Delta \Delta \mathrm{Ct}$ method. Primers sequence for all studied genes is demonstrated in (Table 1). 
Table 1: Primers sequence for all studied genes.

\begin{tabular}{clc}
\hline Gene symbol & \multicolumn{1}{c}{ Primers sequence $\left(5^{`}\right.$ ' $\left.^{\prime}{ }^{\prime}\right)$} & Gene bank accession number \\
\hline Caspase 3 & $\begin{array}{l}\text { Forward GCTATTGTGAGGCGGTTGT } \\
\text { Reverse TGTTCCCTGAGGTTTGC }\end{array}$ & NM032991 \\
TNF- $\alpha$ & $\begin{array}{l}\text { Forward AAAGCTTATGAGCACTGAAAGCATCAT } \\
\text { Reverse TGTAGATCACAGGGCAATGATCCCAAAG }\end{array}$ & KF887972 \\
VEGF & $\begin{array}{l}\text { Forward GTGGACATCTTCCAGGAGTA } \\
\text { Reverse TCTGCATTCACATCTGCTGT }\end{array}$ & XM011354722 \\
18sRNA & $\begin{array}{l}\text { Forward CAGCCACCCGAGATTGAGCA } \\
\text { Reverse TAGTAGCGACGGGCGGGTGT }\end{array}$ & JX132355.1 \\
\hline
\end{tabular}

\section{Statistical analysis}

Results are expressed as mean \pm standard error of mean (SEM) and analyzed for statistically significant differences using one-way analysis of variance (ANOVA) followed by the least significant difference (LSD) post hoc test to compare the means from different groups or t-test if comparing between two group. $P<0.05$ was considered significant. SPSS 17 for Windows was used for statistical calculations (IBM SPSS Statistics, San Diego, California, USA).

\section{RESULTS}

\section{Characterization of Silver Nanoparticles}

Zeta potential measurements of Ag NPs1 and Ag NPs2 are compared in Table2. Ag NPs in aqueous solution carry negative charges due to the presence of $\mathrm{Ag}(\mathrm{OH}) 2$ species on its surface, which result from oxidation of metallic silver in the presence of Oxygen ${ }^{[19,20]}$. AgNPs2have stronger electrostatic repulsion force than Ag NPslas it has more negative mean value of Zeta potential.

Size distributions of Ag NPs 1 and Ag NPs2 are illustrated in (Figure 1). Their Zeta potential values indicate that they are electrically stable, which may be the main reason of achieving a narrow particle size distribution. In addition, both samples have surface charge (strongly anionic) which makes them suitable for biological applications ${ }^{[21]}$.

HR-TEM analysis of silver nanoparticles showed that Ag NPs1 sample was composed of uniform spherical shaped nanoparticles with mean size around $9.02 \mathrm{~nm}$ (Figure 2a). Whilst Ag NPs2 sample was formed of bigger nanoparticles, average size about $24.3 \mathrm{~nm}$ but their shape was uncontrolled with some aggregations (Figure 2b).

\section{Cytotoxicity assay (MTT)}

The applications of Ag NPs1 and AgNPs2 revealed a dose-dependent cytotoxicity on HEP-G2 as shown in (Figure 3). The pattern of their responses is very similar but the individual IC50 was different at 20.6 and 16.3 $\mathrm{nmole} / \mathrm{ml}$ respectively. Induction of apoptosis was the main underlying mechanism of cytotoxicity. The inverted microscope illustrated the presence of these morphological changes of apoptosis (e.g. cell shrinkage, apoptotic bodies) in (Figure 4)

\section{q RT-PCR results}

Relative expression of mRNA of VEGF was significantly upregulated in both HEP-G2 and MCF7 untreated cell lines when compared to normal melanocytes control cell line (Table 3). On the contrary, alterations in Caspase 3 and TNF- $\alpha$ genes level expression in cancer cells were minimal in comparison to normal cell lines (Table 3 ).

\section{Effect of silver nanoparticleson Caspase 3, TNF-a and VEGFgenes level expression on human normal melanocytes}

On normal melanocyte cell line, the two forms of Ag NPs had an insignificant effect on gene level expression of Caspase 3. Similarly, there was insignificant downregulation in VEGF and TNF- $\alpha$ genes expression level in response to Ag NPs1 whilst there was a significant downregulation in both genes expression level in response to Ag NPs2 as shown in (Figure 5)

Effect of silver nanoparticles on Caspase 3, TNF- $\alpha$ and VEGF genes' expression on HEP-G2 and MCF7

HEP-G2and MCF7 cell lines response to $\mathrm{Ag}$ NPs1 and $\mathrm{Ag}$ NPs2 is shown in (Figure 6 and Figure 7) respectively. Caspase 3 gene expression level was considerably upregulated after application of both forms of Ag-NPs. Whilst exposure to $\mathrm{Ag}$ NPs1 led to insignificant downregulation in VEGF and unremarkable upregulation in TNF- $\alpha$, Ag NPs 2 led to significant downregulation in VEGF gene expression level and remarkable upregulation in TNF- $\alpha$ gene expression level compared to their untreated group. 

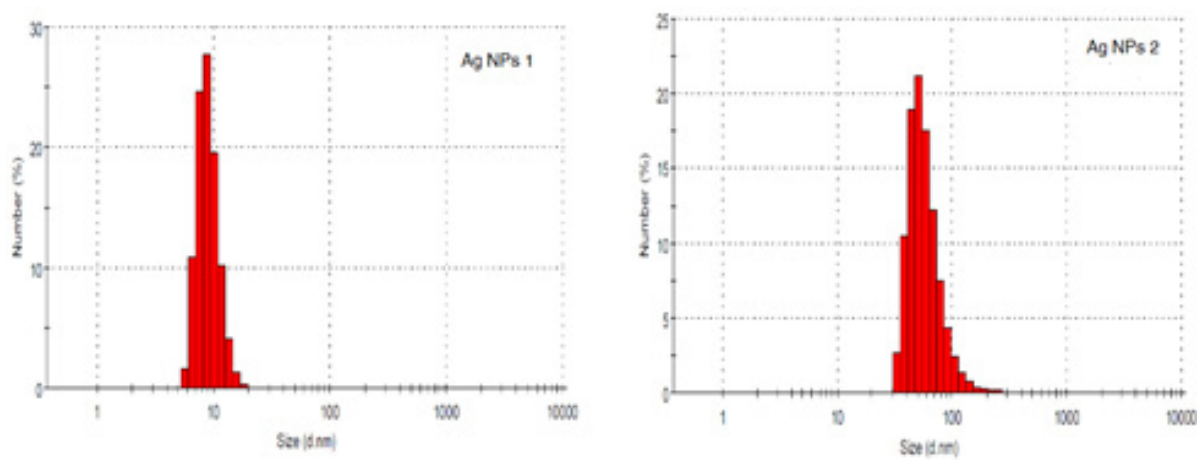

Fig. 1: The particle size distribution of Ag NPs investigated in the aqueous medium using Zetasizer.

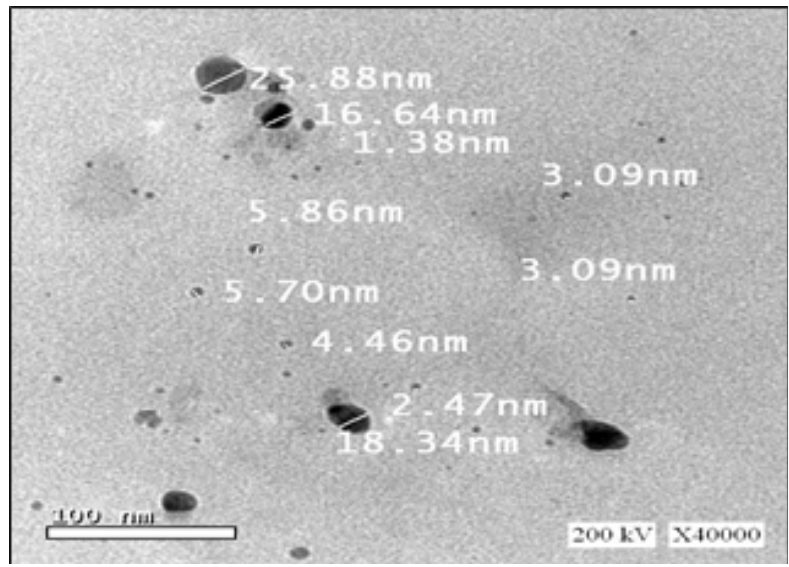

(a)

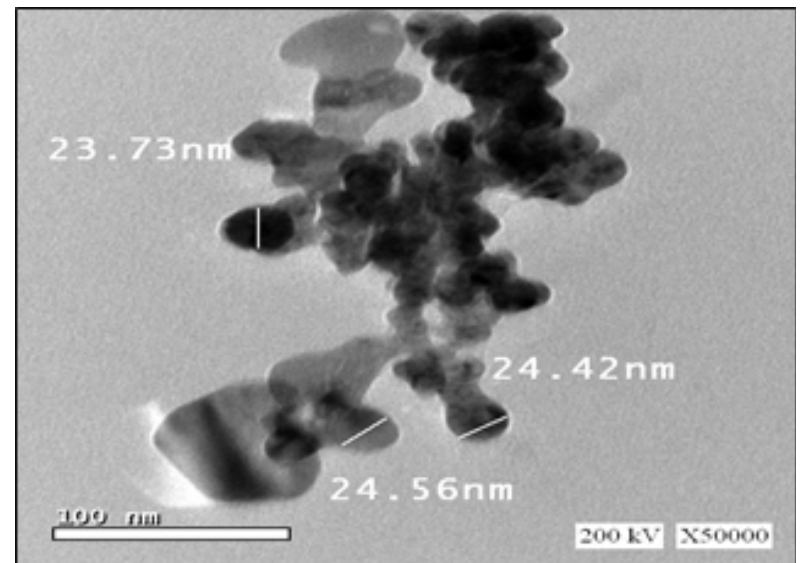

(b)

Fig. 2: HR-TEM analysis of silver nanoparticles. (a) AgNPs1 and (b) AgNPs2.

\section{Hep-G2}

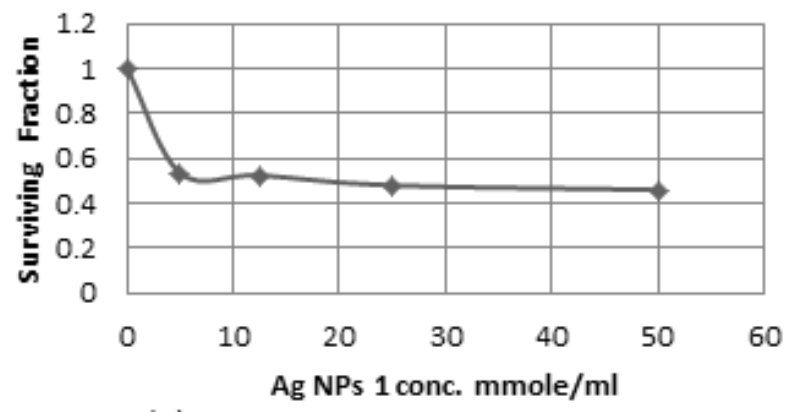

(a)

- -Hep- G2 and Ag NPs 1

\section{Hep-G2}

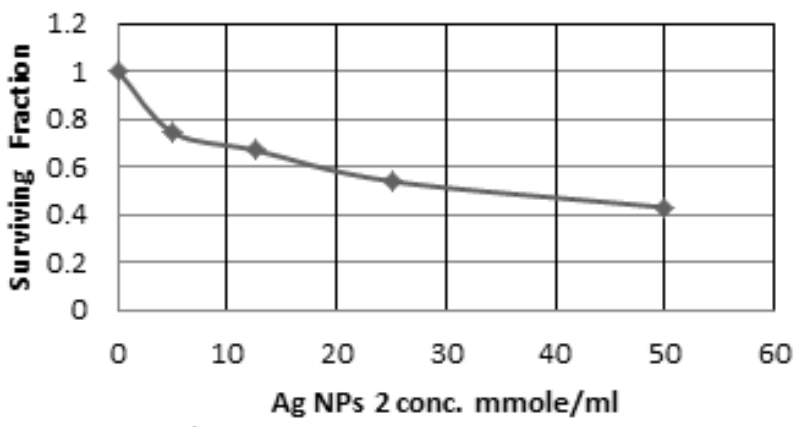

(b)

Fig. 3: Calculation of IC50. (a) Ag NPs1 and (b) Ag NPs2. 

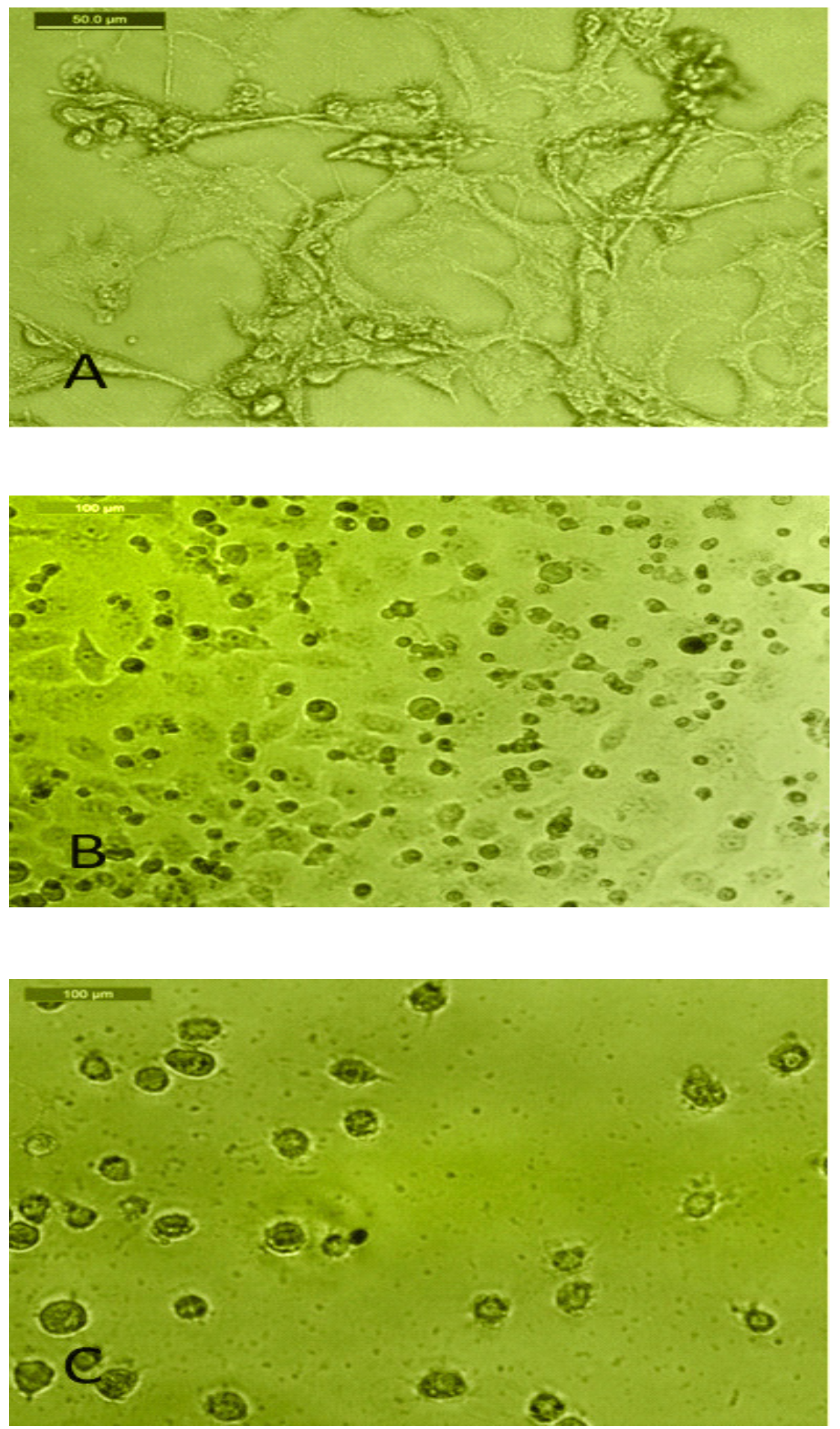

Fig. 4: Hep-G2 cells. (a) Untreated: 80-90\% confluent, glistening, viable without apoptotic changes, (b) After treatment with AgNPs1, 20-30\% confluent cells, the rest of cells are detached, lost glistening, viability (thick arrow) and apoptotic changes (rounding, shrinkage, arrow heads, and apoptotic bodies thin arrows) and (c) After treatment with Ag NPs2, only cells with apoptotic changes, no viable glistening cells (photomicrograph by phase contrast inverted microscope). 


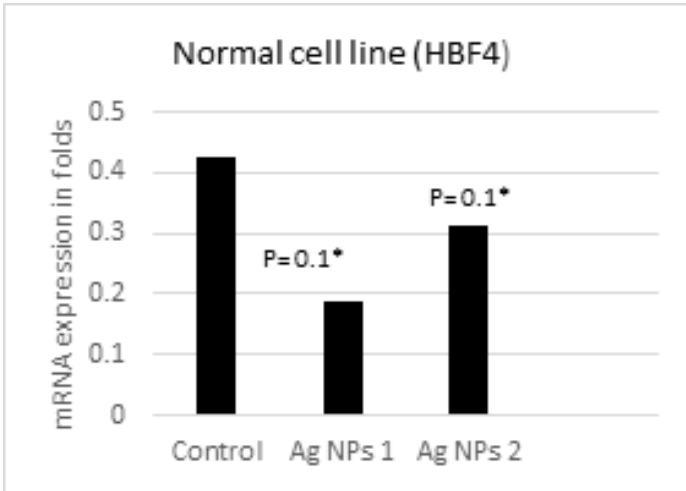

- Caspase 3
Normal cell line (HBF4)

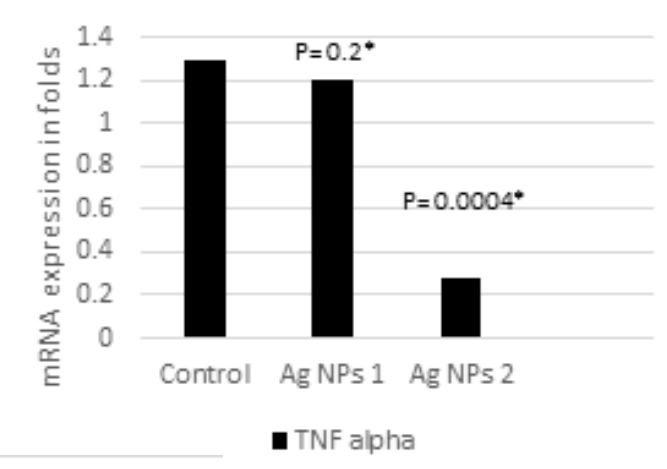

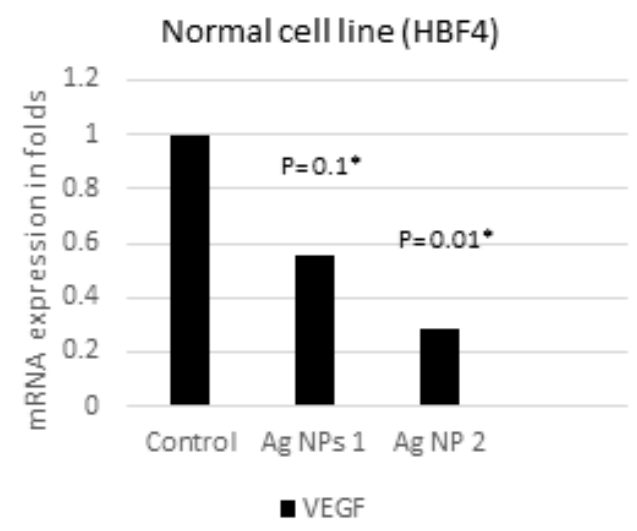

Fig. 5: Effect of Ag NPs on mRNA expression level of Capsase 3, TNF- $\alpha$ and VEGF in normal human melanocyte cell line (HBF4). mRNA expression level of various genes were analyzed relative to18sRNA measured by qRT-PCR.

*p value in comparison to the corresponding control
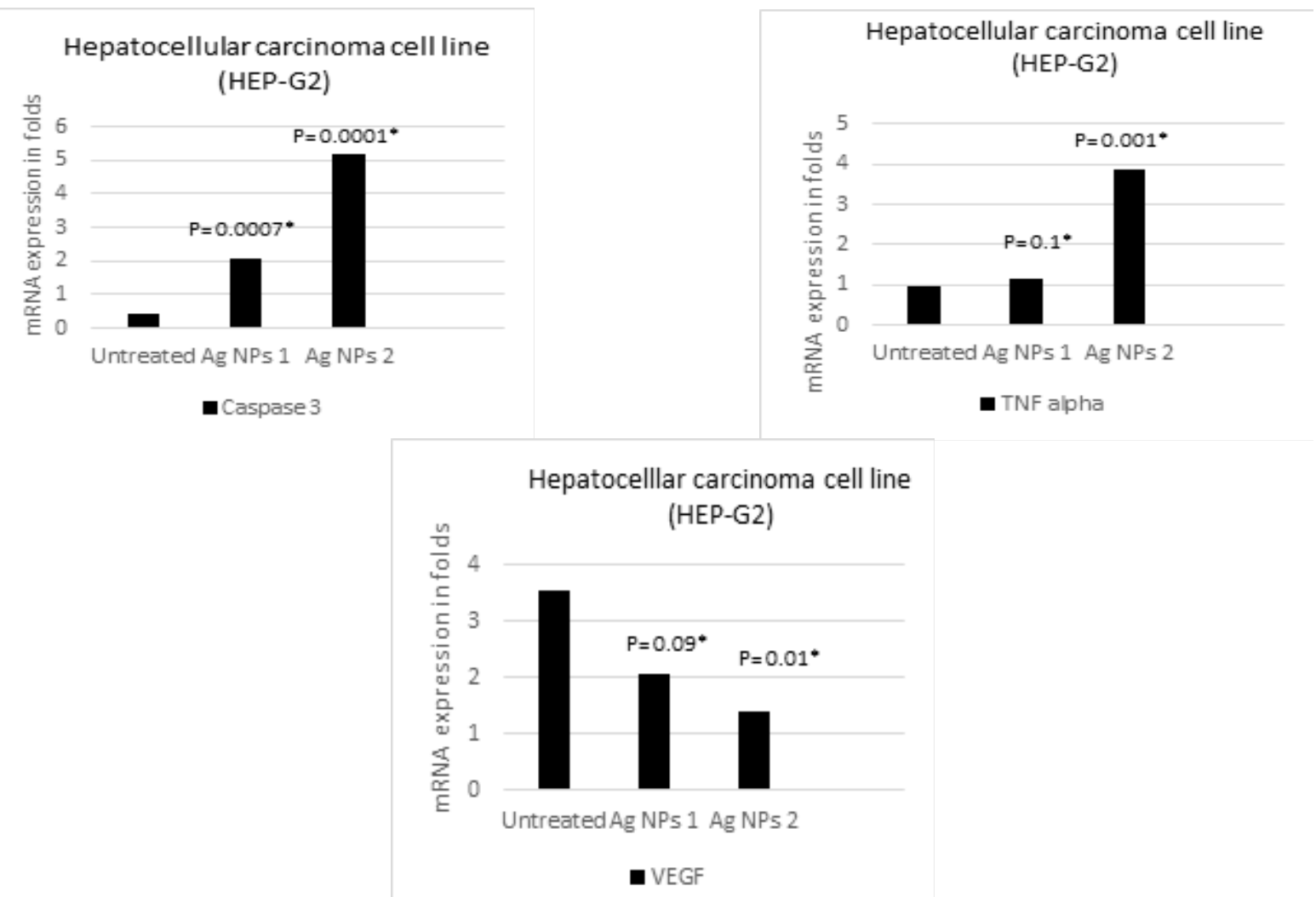

Fig. 6: Effect of Ag NPs on mRNA expression level of Caspase 3, TNF- $\alpha$ and VEGF in liver cancer cell line (HEP- G2). mRNA expression level of various genes were analyzed relative to 18 sRNA measured by qRT-PCR.

*p value in comparison to the corresponding untreated group 


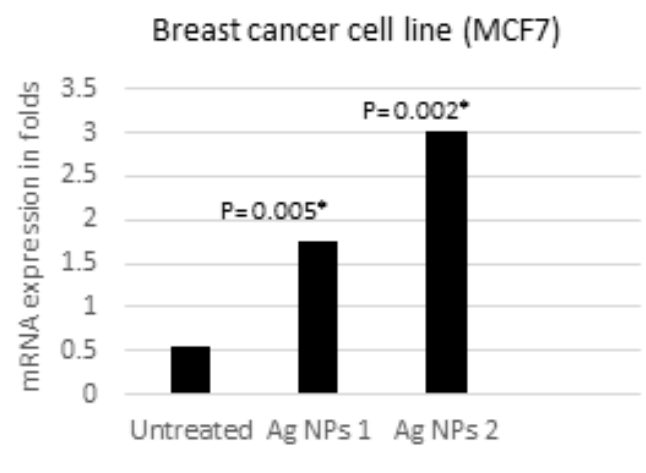

- Caspase 3

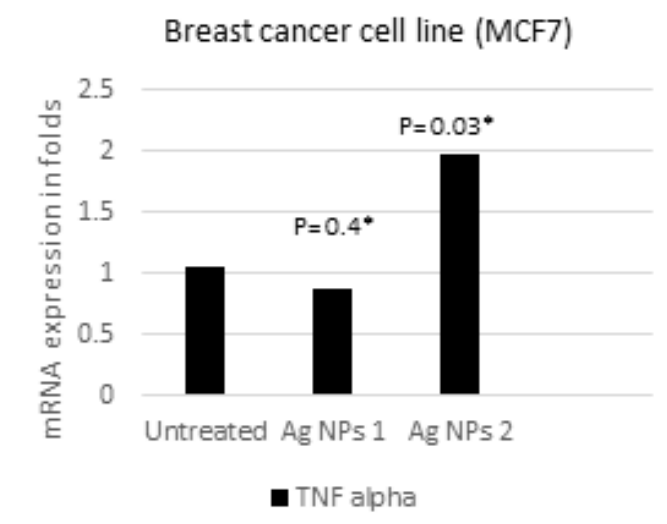

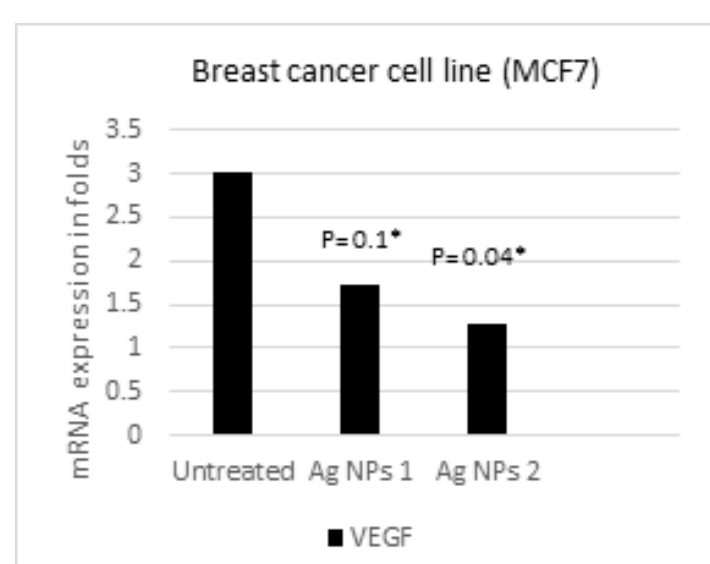

Fig. 7: Effect of Ag NPs on mRNA expression level of Caspase 3, TNF- $\alpha$ and VEGF in breast cancer cell (MCF7). mRNA expression level of various genes were analyzed relative to 18 sRNA measured by qRT-PCR.

*p value in comparison to the corresponding untreated group.

Table 2: Zeta potential measurements of Ag NPs in a solution form

\begin{tabular}{lcc}
\hline Sample & Ag NPs1 & Ag NPs2 \\
\hline Zeta potential $(\mathrm{mV})$ & -23 & -29.1 \\
Size $(\mathrm{nm})$ & 9.02 & 24.3 \\
Conductivity $(\mathrm{mS} / \mathrm{Cm})$ & 0.0593 & 0.176 \\
\hline
\end{tabular}

Table 3: Descriptive statistics of the Rt-PCR expression of the studied genes in control/untreated cell lines

\begin{tabular}{|c|c|c|c|c|c|}
\hline & \multicolumn{5}{|c|}{ mRNA gene expression relative to18sRNA in untreated cell lines } \\
\hline & $\begin{array}{c}\text { HBF4 } \\
\text { Mean } \pm \text { SEM }\end{array}$ & $\begin{array}{c}\text { HEP-G2 } \\
\text { Mean } \pm \text { SEM }\end{array}$ & $P$-value ${ }^{*}$ & $\begin{array}{c}\text { MCF7 } \\
\text { Mean } \pm \text { SEM }\end{array}$ & $P$-value $e^{\#}$ \\
\hline Caspase 3 & $0.4237 \pm 0.1313$ & $0.4212 \pm 0.090$ & 0.9 & $0.5418 \pm 0.10305$ & 0.5 \\
\hline TNF- $\alpha$ & $1.2893 \pm 0.1122$ & $0.9493 \pm .13626$ & 0.08 & $1.0585 \pm 0.16120$ & 0.3 \\
\hline VEGF & $0.9953 \pm 0.19523$ & $2.0536 \pm .22280^{*}$ & 0.009 & $3.0223 \pm .52648$ & 0.002 \\
\hline
\end{tabular}

SEM: standard error of mean

* Compared to HBF4

\# Compared to HBF4 


\section{DISCUSSION}

Nanomaterials, specifically silver nanoparticles, with their unique physical characteristics could provide new molecules for cancer therapy. The therapeutic effect of silver nanoparticles may elicit through manipulation of their physical characteristics ${ }^{[22]}$. Consequently, this study aimed at examining 2 different forms of silver nanoparticles and illustrating their cytotoxicity on human normal melanocytes(HBF4) and 2 different cancer cell lines(MCF7 and HEP-G2) as well as evaluating the changes in some markers involved in carcinogenesis. The characterization of both materials revealed the precise mean size of Ag NPs 1 to be $9.02 \mathrm{~nm}$ and that of Ag NPs 2 was $24.3 \mathrm{~nm}$. Both samples have negative surface charge and they were stable as their Zeta potential was between \pm 10 to $\pm 30^{[23,24]}$. In addition, nanoparticles with surface charge (either positive or negative) have more cytotoxic effect in comparison with their neutral counterparts ${ }^{[25]}$. Regarding their shape, Ag NPs1was spherical and dispersed while Ag NPs 2 was of unfixed shape with aggregations. Different shapes of nanomaterial were described in the literature, which included the spherical forms and many other shapes with occasional formation of aggregates ${ }^{[26,27,28]}$. The shape of silver nanomaterial affects their biological activity. Whilst silver nanospheres acted as strong antibacterial agent than triangular ones in a study done by Raza et al. ${ }^{[29]}$ and Stoehr et al. ${ }^{[30]}$ described no effect of spherical silver nanoparticles on viability of A549 cells.

The dose dependent effect of silver nanoparticles on cell viability was recorded in this work similar to previous studies $^{[31,32]}$. The IC50 figures for Ag NPs 1 and Ag NPs 2, when applied to HEP-G2 were 20.6 and $16.3 \mathrm{nmol} / \mathrm{ml}$ respectively. Application of these IC50 of either silver nanoparticles on normal human melanocyte cell line, for 24 hours, showed negligible changes in the cellular morphology. On the other hand, both forms of Ag NPs led to comparable cell death with considerable apoptotic changes in HEP-G2 and MCF7 cell lines. Induction of apoptosis explained the decrease in cell viability in previous works particularly with negatively charged nanoparticles ${ }^{[32,33]}$. Azizi et al. ${ }^{[34]}$ studied the effect of silver nanoparticles on multiple cell lines and each had a different IC50. In their work, MCF7 cell line's IC50 was $21 \mathrm{nmole} / \mathrm{ml}$, which is close to the figures observed in this experiment. However, diversity of IC50 of silver nanomaterial was noted in previous researches ${ }^{[32,35,36]}$. Yet, there was a difficulty in comparing cytotoxic doses of nanomaterial among various studies because of the use of different ways of expressing the concentration of nanoparticles' solutions as there is still a debate about the dose unit that should be used in nanotoxicology $\mathrm{y}^{[37,38]}$

IC50 was less for Ag NPs 2, though Ag NPs 1 was smaller in size with expected higher toxicity and lower IC50 as previously declared by Liu et al. ${ }^{[39]}$ and Zhang et al. ${ }^{[40]}$. However, the effect of nanoparticles on cell viability depends, in addition to their size, on other factors like their shape, surface charge and degree of repulsion between particles as well as the presence of aggregations, which in this work were in favor of Ag NPs $2^{[26,30,41]}$.

Regarding the evaluated genes in this work, the level of mRNA gene expression of VEGF gene was significantly higher in both malignant cell lines in comparison to their magnitudes in normal human melanocytes. This finding was anticipated because of the documented role of VEGF gene in the development of breast and liver carcinoma ${ }^{[42,43]}$. However, there was no significant difference between levels of Caspase 3 and TNF- $\alpha$ genes' expression between the control/untreated groups of the 3 examined cell lines, which indicates that abnormalities of this cascade were not involved in the process of carcinogenesis in those cancer cell lines supposed to the experiment.

In this study, application of Ag NPs 1 on normal human melanocyte cell led to insignificant alterations in all assessed markers in comparison to the control. Meanwhile Ag NPs 2 induced unremarkable changes in Caspase 3 mRNA gene expression level and considerable downregulation in both VEGF and TNF- $\alpha$. As the TNF- $\alpha$ gene downregulation (being apoptotic inducer) could counteract the downregulation of VEGF (growth promotor), this would explain the observed insignificant morphological changes in these cells upon exposure to either sample of Ag NPs. Similarly, Azizi et al. ${ }^{[34]}$ observed no effect on normal cells exposed to silver nanomaterial (mean diameter $4.6 \mathrm{~nm}$ ) at concentration of $21 \mathrm{nmol} / \mathrm{ml}$ for 24 hours and Sriram et al. ${ }^{[44]}$ reported little effect of silver nanoparticles (size $50 \mathrm{~nm}$, concentration $0.5 \mathrm{nmole} / \mathrm{ml}$ ) on normal cell line. On the other hand, AgNPs led to comparable cell death with considerable apoptotic changes as well as alterations in the levels of the evaluated genes in HEP-G2 and MCF7 cell lines. Where Ag NPs 2 induced significant decrease in VEGF gene expression level, and a rise in Caspase 3 and TNF- $\alpha$ genes' expression level, Ag NPs 1 led to significant upregulation of Caspase 3 and unremarkable changes in VEGF and TNF- $\alpha$ gene expression levels in both HEP-G2 and MCF7. Therefore, the underlying molecular changes induced by either nanoparticle were not exactly the same. Yang et $a .^{[45]}$ described the inhibitory effect of silver nanoparticle on VEGF gene expression. In concordance with current results, Baharara et al. ${ }^{[28]}$ described a Caspase 3 gene upregulation in cell lines upon application of Ag NPs. However, Caspase 3 upregulation in response to Ag NP2, in each cell line, was much higher than its increase in response to Ag NPs 1. The reason for this difference is that Ag NPs2 led to significant increase in TNF- $\alpha$ gene expression that in turn augment Caspase 3 upregulation $^{[46]}$ while Ag NPs 1 did not result in a remarkable change in TNF- $\alpha$ gene expression. Herzog et al. ${ }^{[47]}$ reported no effect of Ag NPs on the cellular level of TNF- $\alpha$ gene expression similar to Ag NPs 1 in this experiment. Contrarily to the present findings, Parnsamut and Brimson ${ }^{[48]}$ reported a TNF- $\alpha$ gene downregulation in T-lymphocyte leukemic (Jurkat) cells in response to Ag NPs, however, the dose they applied was below their calculated IC50. This variability in genes expression levels could illustrate the molecular 
basis for the lower IC50 of Ag NPs 2 compared to Ag NPs 1 despite the smaller size of the later. Nevertheless, all the aforementioned genes' changes induced by the application of either Ag NPs led to decline in malignant cell proliferation and increase in their rate of death.

\section{CONCLUSION}

In conclusion, silver nanoparticles induce dosedependent cytotoxicity. However, their effective dose depends on their size, shape and surface charge as well as the nature of cells. Silver-nanomaterials can selectively affect MCF7 and HEP-G2 cell lines with negligible influence on normal melanocytes. Ag NPs inhibit either malignant cell lines survival by down regulating angiogenesis and tumor growth inducing marker VEGF and they stimulate apoptotic cell death via upregulation of Caspase 3 and TNF- $\alpha$.Consequently, silver nanoparticles are candidate to be an effective recommended therapy for breast and hepatocellular carcinoma. Further studies investigating their influence on various cell lines and examining alterations in additional genes are prerequisite to ensure their safety and efficacy as an anticancer agent.

\section{CONFLICTS OF INTEREST}

There are no Confelicts of Interest.

\section{REFERENCES}

1. Teli MK, Mutalik S, Rajanikant GK: Nanotechnology and nanomedicine: going small means aiming big. Curr Pharm Des. (2010) 16(16):1882-1892.

2. De Berardis B, Civitelli G, Condello $M$ et al.: Exposure to $\mathrm{ZnO}$ nanoparticles induces oxidative stress and cytotoxicity in human colon carcinoma cells. Toxicol Appl Pharmacol. (2010) 246(3): 116-127.

3. Li CZ, Male KB, Hrapovic S, Luong J: Fluorescence properties of gold nanorods and their application for DNA biosensing. Chem Commun. (2005) 31:3924-3926.

4. De Jong WH and Borm PJ: Drug delivery and nanoparticles: applications and hazards. Int J Nanomedicine. (2008) 3(2): 133-149.

5. He Y, Du Z, Ma S et al.: Effects of greensynthesized silver nanoparticles on lung cancer cells in vitro and grown as xenograft tumors in vivo. Int J Nanomedicine. (2016) 11:1879-1887.

6. Sayed R, Saad H, Hagagy N: Silver nanoparticles: characterization and antibacterial properties. Rendiconti Lincei. Scienze Fisiche e Naturali. (2018) 29: 81-86.

7. Zhang XF, Shen $\mathrm{W}$ and Gurunathan S: Silver Nanoparticle-Mediated cellular responses in various cell lines: An in vitro model. Int J Mol Sci. (2016) 17 (10): 1603-1629.
8. American Cancer Society. Cancer Facts and Figures (2015) Atlanta, USA.

9. Satchell P, Gutmann J and Witherspoon D: Apoptosis: an introduction for the endodontist. Int Endod J. (2003) 36 (4): 237-245.

10. Goel HL, Mercurio AM: VEGF targets the tumour cell. Nat Rev Cancer. (2013) 13(12): 871-882.

11. Riedl SJ and Shi Y: Molecular mechanisms of caspase regulation during apoptosis. Nat Rev Mol Cell Biol. (2004) 5:897-907.

12. Persad R, Liu C, Wu TT et al.: Overexpression of caspase-3 in hepatocellular carcinomas. Mod Pathol. (2004)17: 861-867.

13. Jeyaraj M, Renganathan A, Sathishkumar G et al.: Biogenic metal nanoformulations induce $\mathrm{Bax} / \mathrm{Bcl} 2$ and caspase mediated mitochondrial dysfunction in human breast cancer cells (MCF-7). RSC Adv. (2015) 5(3): 2159-2166.

14. Baxter GT, Kuo RC, Jupp OJ, Vandenabeele P, MacEwan DJ: Tumor Necrosis Factor- $\alpha$ mediates both apoptotic cell death and cell proliferation in a human hematopoietic cell line dependent on mitotic activity and receptor subtype expression. J Biol Chem. (1999) 274: 9539-9547.

15. Mendoza FJ, Espino PS, Cann KL, Bristow N, McCrea K, Los M: Antitumor chemotherapy utilizing peptide-based approaches - apoptotic pathways, kinases, and proteasome as targets. Arch Immunol Ther Exp. (2005) 53(1):47-60.

16. Li L, Wei XH, Pan YP et al.: LAPTM4B: a novel cancer- associated gene motivates multidrug resistance through efflux and activating PI3K/AKT signaling. Oncogene. (2010) 29(43): 5785-5795.

17. Firdhouse J, Lalitha P: Apoptotic efficacy of biogenic silver nanoparticles on human breast cancer MCF-7 cell lines. Prog Biomater. (2015) 4: 113-121.

18. Skehan P, Storeng S, Scudiero D, et al.: New colorimetric cytotoxicity assay for anticancerdrug screening. J Natl Cancer Inst. (1990) 82: 1107-1112.

19. Jewett DG, Hilbert TA, Logan BE et al.: Bacterial transport in laboratory columns and filters: influence of ionic strength and $\mathrm{pH}$ on collision efficiency. Water Res. (1995) 29 (7): 1673-1680.

20. Zhang Hand Oyanedel-Craver V: Evaluation of the disinfectant performance of silver nanoparticles in different water chemistry conditions. J Environ Eng. (2012) 138 (1): 58-66.

21. Selvi BCG, Madhavan J, Santhanam A: Cytotoxic effect of silver nanoparticles synthesized from Padina tetrastromatica on breast cancer cell line. Adv Nat Sci.: Nanosci Nanotechnol. (2016) 7 (3)35015:1-8. 
22. Thorley AJ and Tetley TD: New perspectives in nanomedicine. Pharmacol Ther. (2013) 140 (2): 176-185.

23. O'Brien RW: Electroacoustic studies of moderately concentrated colloidal suspensions. Faraday Discussions of the Chemical Society (1990) 90: 301-312.

24. Hanaor D, Michelazzi M, Leonelli $\mathrm{C}$ et al.: The effects of carboxylic acids on the aqueous dispersion and electrophoretic deposition of $\mathrm{ZrO} 2$. $\mathrm{J}$ of the European Ceramic Society. (2012) 32: $235-244$

25. Schaeublin NM, Braydich-Stolle LK, Schrand AM et al.: Surface charge of gold nanoparticles mediates mechanism of toxicity. Nanoscale. (2011) 3(2): 410-420.

26. Okuda-Shimazaki J, Takaku S, Kanehira K, Sonezaki S, Taniguchi A: Effects of titanium dioxide nanoparticle aggregate size on gene expression. Int J Mol Sci. (2010) 11(6): 2383-2392.

27. Khodashenas B, Ghorbani HR: Synthesis of silver nanoparticles with different shapes. Arabian J of Chemistry. (2015): 1-16.

28. Baharara J, Namvar F, Ramezani T, Mousavi M, Mohamad R: Silver Nanoparticles Biosynthesized Using Achilleabiebersteinii Flower Extract: Apoptosis Induction in MCF-7 Cells via Caspase Activation and Regulation of Bax and Bcl-2 Gene Expression. Molecules. (2015) 20(2): 2693-2706.

29. Raza MA, Kanwal Z, Rauf A et al.: Size- and shape-dependent antibacterial studies of silver nanoparticles synthesized by wet chemical routes. Nanomaterials. (2016) 6(74): 1-15.

30. Stoehr LC, Gonzalez E, Stampfl A, Casals E, Duschl A, Puntes V, Oostingh GJ: Shape matters: Effects of silver nanospheres and wires on human alveolar epithelial cells. Part Fibre Toxicol. (2011) 8: $425-430$.

31. Piao MJ, Kang KA, Lee IK, Kim HS, Kim S, Choi JY, Choi J, Hyun JW: Silver nanoparticles induce oxidative cell damage in human liver cells through inhibition of reduced glutathione and induction of mitochondria involved apoptosis. Toxicology Lett. (2011) 201 (1): 92- 100

32. Gurunathan S, Han JW, Eppakayala V et al.: Cytotoxicity of Biologically synthesized silver nanoparticles in MDA-MB-231 human breast cancer cells. Biomed Res Int. (2013) ID535796: 1-10.

33. Fröhlich E: The role of surface charge in cellular uptake and cytotoxicity of medical nanoparticles. Int J Nanomedicine. (2012) 7: 5577-5591.
34. Azizi M, Ghourchian H, Yazdian F, Bagherifam S, Bekhradnia S, Nystrom B: Anti-cancerous effect of albumin coated silver nanoparticles on MDA-MB 231 human breast cancer cell line. Sci Reports. (2017) 7(5178): 1-18.

35. Zanette $\mathrm{C}$, Pelin M, Crosera $\mathrm{M}$ et al.: Silver nanoparticles exert a long-lasting anti-proliferative effect on human keratinocyte $\mathrm{HaCaT}$ cell line. Toxicol in Vitro. (2011) 25(5): 1053-1060.

36. Faedmalekia F, Shirazib FH, Salarianc AA, AhmadiAshtiani H, Rastegar H: Toxicity effect of silver nanoparticles on mice liver primary cell culture and HepG2 cell line. Iran J Pharm Res. (2014) 13(1): 235-242.

37. DeLoid G, Cohen JM, Pyrgiotakis G et al.: Advanced computational modeling for in vitro nanomaterial dosimetry. Part and Fibre Toxicol. (2015): 12-32.

38. Kettler K, Krystek P, Giannakou C, Hendriks AJ, Jong WH: Exploring the effect of silver nanoparticle size and medium composition on uptake into pulmonary epithelial 16HBE14o-cells. J Nanopart Res. (2016) 18(182): 1-11.

39. Liu XL, Lee PY, Ho CM et al.: Silver nanoparticles mediate differential responses in keratinocytes and fibroblasts during skin wound healing. Chem Med Chem. (2010) 5(3): 468-475.

40. Zhang Y, Yu W, Jiang X, Lv K, Sun S, Zhang $\mathrm{F}$ : Analysis of the cytotoxicity of differentially sized titanium dioxide nanoparticles in murine MC3T3-E1 preosteoblasts. J Mater Sci. (2011) 22(8): 1933-1945.

41. Lankoff A, Sandberg WJ, Wegierek-Ciuk A et al.: The effect of agglomeration state of silver and titanium dioxide nanoparticles on cellular response of HepG2, A549 and THP-1 cells. Toxicol Lett. (2012) 208:197-213.

42. Bachelder RE, Crago A, Chung J, Wendt MA, Shaw LM, Robinson G, Mercurio AM: Vascular endothelial growth factor is an autocrine survival factor for Neuropilin-expressing breast carcinoma Cells. Cancer Res. (2001) 61:5736-5740.

43. Fernandez M, Semela D, Bruix J, Colle I, Pinzani $\mathrm{M}$, Bosch J: Angiogenesis in liver disease. J of Hepatol. (2009) 50: 604-620.

44. Sriram MI, Kanth SBM, Kalishwaralal K, Gurunathan S: Antitumor activity of silver nanoparticles in Dalton's lymphoma ascites tumor model. Int J Nanomedicine. (2010) 5:753-762.

45. Yang T, Yao Q, Cao F, Liu Q, Liu B, Wang $\mathrm{XH}$ : Silver nanoparticles inhibit the function of hypoxia-inducible factor-1 and target genes: insight into the cytotoxicity and antiangiogenesis. Int J Nanomedicine. (2016) 11: 6679-6692. 
46. Zhao X, Bausano B, Pike BR et al.: TNF- $\alpha$ stimulates caspase- 3 activation and apoptotic cell death in primary septo-hippocampal cultures. J Neurosci Res. (2001) 64: 121-131.

47. Herzog F, Clift JDM, Piccapietra F et al.: Exposure of silver-nanoparticles and silver ions to lung cells in vitro at the air-liquid interface. Part Fibre Toxicol. (2013) 10(11): 2-14.

48. Parnsamut $\mathrm{C}$ and Brimson S: Effects of silver nanoparticles and gold nanoparticles on IL-2, IL-6, and TNF- $\alpha$ production via MAPK pathway in leukemic cell lines. Genet Mol Res. (2015) 14(2):3650-3668. 
الملخص العربى (المى

\section{در اسمة معملية لخصائص جسيمات الفضة النانوية و تقيم سميتها الخلوية على الخلايا البشرية لسرطان الثثى و الكبد مقابل الخلايا الصبخية الطبيعية \\ رانيا سيد'، دينا صبرى Y ، جمعة مصطفى هيديب ؛ ، ب، حنان حسن محمد على 'معمل مترولوجيا و تكنولوجيا النانو - المعهد القومى للمعايرة

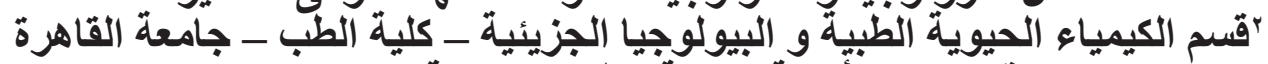

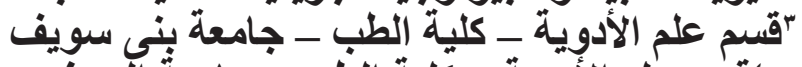

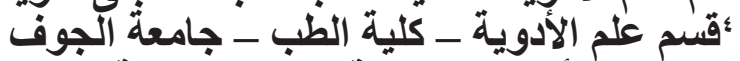

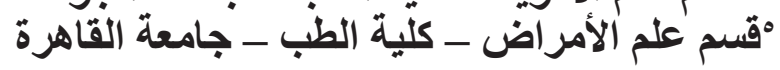

المقدمة: نظر اللخصائص المميزة لجسيمات الفضة النانوية فإنه من الممكن إستخدامها فى المجال الطبى كأحد الطرق

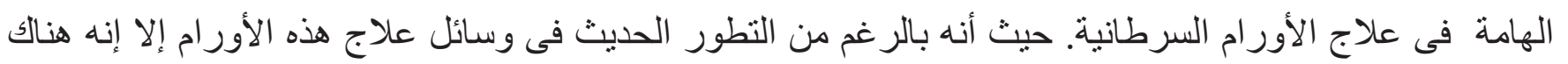
بعض الأورام الخبيثة يصعب علاجها بالو سائل المتاحة. الهدف من البحث: در اسة خصائص نوعين من جسيمات الفضة النانوية (Ag NPs 1 and Ag NPs 2) و مدى لأنى نأثير ها على سرطان الثدى (MCF7) وسرطان الكبد (HEP-G2) و كذلك على الخلايا الصباغية البشرية الطبيعية

( $\mathrm{HBF} 4)$

المواد و الطرق المستخدمة: حملت كل من نوعى جسيمات الفضة النانوية شحنة سالبة على سطحهاو كان متوسط حجم الجسيمات بالنسبة ل (Ag NPs 1 and Ag NPs 2) هو 9.02 نانو متر و 24.6 نانومتر على التو الى. و بإستخدام مقياس MTT وجد أن درجة السمية الخلوية لكل من نوعى جسيمات الفضة النانوية تنتاسب تناسب طردى مع الجر عة المعطاة للخلايا السرطانية (MCF7) و (HEP-G2) مع عدم وجود أى تأثير يذكر على الخلايا الطبيعية (HBF4).

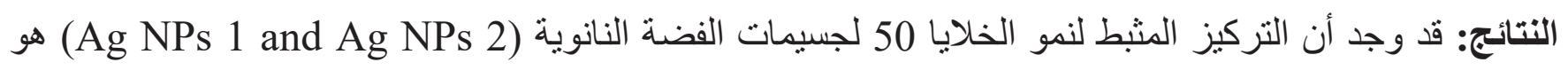
20.06 و 16.03 نانومول/ملليلتر على التوالى. و بإستخدام المجهر الضوئى المقلوب وجد أن موت الخلايا كان عن

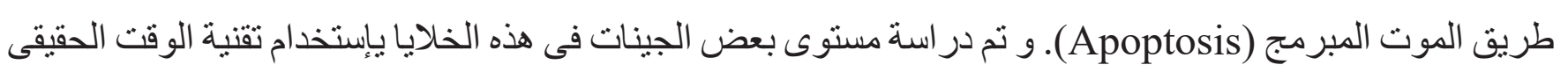
لتفاعل البلمرة مسلسل (RT-PCR) . و قد وجد أن مستوى الجين (Caspase 3) قد تز ايد فى الخلايا السرطانية التى دئى تعرضت لجسيمات الفضة النانوية Ag NPs1 و Ag NPs2 فى حين أن مستوى جين (VEGF) قد تناقص. بالإضافة إلى ذللك فإن مستوى جين (TNF-

2) فقط. على النقيض لم تظهر الخلايا البشرية الصباغية الطبيعية تغيير ذو قيمة فى مستوى هذه الجينات.

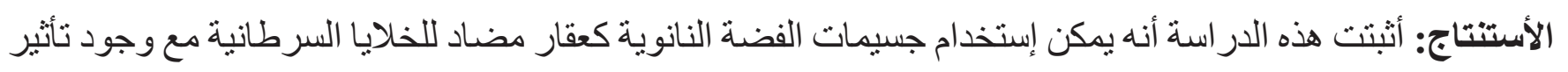

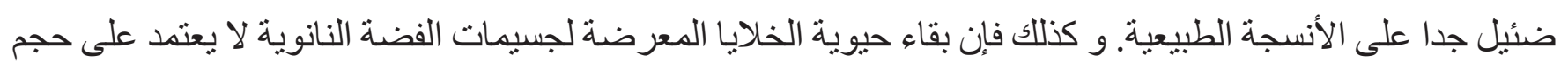
هذه الجسيمات فقطو لكنه يعتمد أيضا على شكلهاو على شحنتها السطحية بالإضافة إلى درجة التباعد و درجة تلاصنق هذه الجسيمات من بعضها. 